LAERE MIDDEL ODK

\title{
Designviden og design- eksperimenter som afsæt for implementering af læringsplatforme i Folkeskolen
}

Af Karsten Gynther og Rasmus Leth Jørnø, Professionshøjskolen Absalon

Korrekt citering af denne artikel efter APA-systemet (American Psychological Association System, 6th Edition): Gynther, K. \& Jørnø, R. L. (2019). Designviden og designeksperimenter som afsæt for implementering af læringsplatforme i Folkeskolen. Learning Tech - Tidsskrift for læremidler, didaktik og teknologi, (6), 56-81. DOI 10.7146/It.v4i6.110924 


\section{Abstract}

I denne artikel præsenteres en brugerinddragende model til understøttelse af implementeringsforløb af digitale læringsplatforme i danske folkeskoler. Den fremsatte model er designet omkring brugerinddragende designprocesser, der understøtter kritisk tematisering, eksemplarisk praksis og innovativ anvendelse af læringsplatforme samt formaliseret videndeling i pædagogiske teams. Med udgangspunkt i modellen kan pædagoger og lærere generere, visualisere og dele eksemplariske erfaringer med anvendelse af de digitale læringsplatforme gennem "designnarrativer" og "designmønstre" for pædagogisk og faglig meningsfuld brug af læringsplatformene. Vi analyserer betydningen af disse processer for implementeringen og ser nærmere på betydningen af at dele designviden i professionelle læringsfællesskaber. Med afsæt i ovenstående stiller vi følgende forskningsspørgsmål: Hvorledes kan brugerinddragende designprocesser fokuseret på pædagogiske og didaktiske praksisser understøtte brugeradoption i teknologiske implementeringsprocesser? Artiklen bygger på empiri fra et større forskningsprojekt initieret af Undervisningsministeriet med involvering af 15 folkeskoler. Som afsæt for denne artikel har vi kombineret dybdegående casestudier på to skoler med projektets tværgående dataindsamling.

This article proposes a model for user involved implementation that supports the development of innovative learning designs subject to standardized technological constraints. In Denmark, all public schools are required to implement a digital learning platform by 2018 that satisfies a requirements specification produced by Local Government Denmark. The Danish Ministry of Higher Education and Science has launched a research project involving 15 public schools in order to generate knowledge on how to best support the implementation of the platforms. The empirical data for this article stems from a subproject addressing this effort. Methodologically this subproject takes its cue from Design Based Research. Using theory on production and sharing of design knowledge in the form of "design narratives", "design patterns" and "design scenarios", the article proposes a double loop implementation model that integrates the participants' analyses of their existing experiences with technology and their proposals for future use of the platforms. 


\title{
Designviden og design- eksperimenter som afsæt for implementering af læringsplatforme i Folkeskolen
}

\section{En dobbeltloop læringsmodel for brugerinvolverende implementering af læringsplatforme}

\author{
Læseguide \\ Artiklens indledes med en præsentation af vores teoretiske \\ perspektiv på og forståelse af implementering af teknologi i en \\ pædagogisk kontekst. Efter en introduktion af projektets metode \\ præsenteres den i projektet udviklede brugerinddragende imple- \\ menteringsmodel, herunder dens teoretiske afsæt og potentielle \\ praktiske anvendelse. Et format for deling af implementering- \\ serfaringer introduceres efterfølgende, hvorefter de generelle \\ projekterfaringer med anvendelse af modellen beskrives og \\ diskuteres.
}

\section{Introduktion}

\section{Kontekst}

I Danmark skulle der på alle danske folkeskoler inden 2018 implementeres en læringsplatform, der lever op til den kravspecifikation, som Kommunernes Landsforening (KL) har udarbejdet. Med henblik på at understøtte implementeringen finansierede det danske undervisningsministerium et forsknings- og udviklingsprojekt, som omfattede 15 skoler i Danmark. 


\section{Teoretisk afsæt}

To af de væsentligste åbne spørgsmål, når ny teknologi inddrages i folkeskolens praksisser, er, hvorvidt brugerne adopterer eller afstøder den nye teknologi og hvorfor? Der findes en del generel teori vedrørende brugeres adaption af nye innovationer (Straub, 2009). En af de mere populære er Rogers (1962/1983, s. 15), der opregner fem forskellige elementer, der afgør brugeres adoption af ny teknologi. Disse fem elementer kan 'oversættes' til en uddannelsessammenhæng som følger:

A. Der skal være en relativ fordel ved at bruge platformene i forhold til eksisterende teknologier.

B. Løsningen skal være kompatibel med eksisterende pædagogiske og didaktiske grundsyn.

C. Kompleksiteten ved at anvende platformene skal være på et passende niveau.

D. Platformene skal være mulige at afprøve på forhånd.

E. De umiddelbare fordele skal være nemme at kommunikere til alle typer af brugere.

Vi går i denne artikel ikke ind i en dybere diskussion af adoptionsteorier, men bruger Rogers model som udgangspunkt til at rammesætte artiklen. Der kræves dog en række forklarende bemærkninger. Rogers model kan forlede en til at tro, at 'teknologien' entydigt kan beskrives (fx teknisk), og at adoptionen er en rationel proces, hvor rationelle aktører vurderer teknologien som et isoleret fænomen for at tage stilling til fordele og ulemper ved teknologien og enten adoptere eller afvise den. Spørgsmålene om, hvad teknologien 'er', og hvordan den eventuelt adopteres, er imidlertid langt mere komplicerede. Forståelsen af, hvad teknologien er, afhænger af observatørens perspektiv, hvorvidt den beskrives teknisk, funktionelt, i sammenhæng med praksis, andre teknologier og ikke mindst den kontekst, den indgår i. I projektet har vi skelnet imellem det intentionelle design, det implementerede design og det opnåede design (McKenney \& Reeves, 2012). Forsimplet kan vi korrelere disse tre med henholdsvis designerens perspektiv, brugerens perspektiv (primært lærere, pædagoger og sekundært elever) og aftagernes perspektiv (lærere, pædagoger, elever, skoleledelse og forældre). Pointen med denne skelnen er at understrege, at der ikke er en lineær sammenhæng mellem det intenderede, det implementerede og det opnåede design. Det skal ikke forstås således, at designerens intentioner 
i forhold til de digitale læringsplatforme er uvæsentlige. Hvad designeren forestiller sig er blot ikke nødvendigvis sådan, som teknologien modtages og anvendes i den givne kontekst. Pointen drejer sig snarere om, at designet transformeres i og med implementeringen.

Vi benytter her begrebet 'udfaldsrum' (Bertelsen, 1997) for at klargøre, hvad der menes. Fra et designperspektiv er det ikke muligt at indfange en situation udtømmende, dvs. beskrive samtlige variable der indgår i og påvirker en situation. I stedet beskrives situationen som et rum af mulige udfald i forhold til en given problematik. Hvert udfald vil adskille sig fra andre mulige udfald på mindst ét parameter, men reelt sandsynligvis flere parametre. Et sådan udfald er således en 'løsning' af problemet. Hvert udfald er underlagt bestemte vilkår eller 'bindinger' (eng. constraints) (Biskjaer \& Halskov, 2014; Jørnø \& Gynther, 2018). Bindinger skal ikke forstås i dagligdags termer som en begrænsning. Bindinger er her et teknisk begreb, der involverer tekniske, sociale, fysiske og designmæssige bindinger, som både muliggør og begrænser et udfald. De mest iøjnefaldende bindinger er materielle og sociale. De materielle bindinger kan iagttages gennem en analyse af designet af de læringsplatforme, der pt. er på markedet. Sociale bindinger er de kontrakter, aftaler, regler, konventioner og ritualer, der er eller vil blive opbygget i forhold til anvendelsen af de digitale læringsplatforme i skolen. At alle skoler i Danmark skal have en digital platform, og at samtlige elever, lærere og forældre i Danmark skal have adgang til en platform, er en social binding for anvendelsen af platformene.

Indsigten i forhold til at forstå teknologi som et udfaldsrum er, at hverken designerne af læringsplatformene, skoleledelsen, der indkøber løsningen, lærerne i deres brug af platformene (Laurillard, 2012) eller teknologiens materielle bindinger opererer i et lukket udfaldsrum. Når nye teknologier, læringsdesign mv. implementeres i skolerne, så er udfaldsrummet for det implementerede design, dvs. den konkrete brug og virkning, "åben", forstået som kontingent og multipel. Der er mange mulige udfald og ingen af dem er tvingende nødvendige. Der er flere aktører, der forsøger at påvirke, hvad teknologien er og gør, og meget sjældent kan en enkelt aktør kontrollere (dvs. lukke) udfaldsrummet. Udfaldsrummet for det opnåede design kan ligeledes først iagttages, når platformene konkret implementeres i praksis i undervisningen. Her afgøres den konkrete implementering, og dermed også den opnåede virkning af brugen af platformen, af 
den specifikke skolekontekst, som platformen implementeres i. Udfaldsrummet set i relation til det intenderede design kan derfor ændres radikalt, da det kan knopskyde, transformere og mutere afhængigt af modtagelsen og konteksten (Hung, Lim \& Huang, 2010). Med andre ord kan læringsplatformenes overordnede mål - at understøtte lærerarbejdet og elevernes læreprocesser, så flere elever lærer mere - ikke alene undersøges ved at undersøge teknologien isoleret. Når dette er sagt, så består en del af designarbejdet omkring det intenderede design stadig i et forsøg på delvist at "lukke" det kontingente udfaldsrum. Dette sker ved at lade teknologien (ofte materielt) vanskeliggøre eller umuliggøre nogle udfald. Et notorisk eksempel er parkbænke designet således, at man ikke kan ligge komfortabelt eller udstrakt på dem for at afskrække hjemløse fra at sove i parkerne.

Et andet væsentligt aspekt ved brugen af udfaldsrum som begreb er, at teknologien altid forstås i en social kontekst og derfor skal ses som et udfald eller konsekvens af og i brug, snarere end som en bestemt artefakt. Al teknologi er filtret ind i sociale praksisser. Det betyder flere ting. For det første er læringsplatforme designet til at understøtte bestemte sociale praksisser. Designerne har foretrukket bestemte udfald over andre. Deres designvalg vil ofte være udtryk for bestemte normer og forståelser. Dernæst vil den eksisterende praksis, teknologien søges implementeret i, efter al sandsynlighed allerede være udtryk for bestemte teknologier og valg, som den nye teknologi søger at ændre, erstatte eller eliminere. I relation til teknologiadoption betyder det, at det ikke blot er den nye teknologi, der er til overvejelse. Den tilbudte teknologi måles direkte op imod eksisterende teknologibrug og praksis.

På baggrund af dette forstår vi ikke implementering af teknologi som en proces, der kan styres som en "vandfaldsmodel", sådan som man kender det fra nogle ITimplementeringsprojekter. Forståelsen af processer omkring teknologiimplementeringer og adoptioner er derimod bedre hjulpet ved at afdække, hvordan designintentioner transformeres i en kontekst. Fra et skoleudviklingsperspektiv er det vores hypotese, at en implementeringsproces således bedst understøttes ved, at der fokuseres på processer, der faciliterer teknologiadoption.

Med ovenstående in mente kan Rogers fem elementer sættes i relation til, hvad en del af litteraturen siger om adoption af teknologi i skoler. Overordnet kan vi sige, at nuværende og kom- 
mende brugere af platformene generelt er bekymrede for implementeringen af disse teknologier (Lochner, Conrad \& Graham, 2015) særligt i forhold til, om de får indflydelse på, hvordan platformene skal implementeres. De relative fordele (A) læringsplatforme påstås at tilbyde inkluderer eksempelvis at øge elevernes læringsudbytte (Edmunds \& Hartnett, 2014), lette undervisernes daglige forberedelse og arbejde med målstyring samt forbedre kommunikation mellem skole og hjem. Her er læringsplatformene således netop oppe imod eksisterende (primært) analoge praksisser. Platformene opleves som tidskrævende at bruge, og det er svært for underviserne at se en pædagogisk merværdi ved brug af platformene overfor eksisterende pædagogisk praksis (Underwood \& Stiller, 2013). Underviserne oplever, at eksisterende platforme mest indsamler data om undervisningen i stedet for at understøtte elevernes læreproces (Selwyn, 2011). En analyse af læringsplatformene på det danske marked understøtter dette, idet disse platforme primært er designet til at understøtte lærernes planlægning, evaluering og professionelle udvikling, mens platformene kun i begrænset omfang understøtter selve interaktionen mellem lærerne og eleverne i klasserummet (Jørnø \& Gynther, 2018). Hvorvidt læringsplatformene er kompatible (B) med eksisterende pædagogiske og didaktiske grundsyn er derfor et åbent spørgsmål. Lærerne er her særligt bekymrede for, om platformen standardiserer undervisningen (Selwyn, 2011). Det er derfor afgørende, i hvilket omfang læringsplatformen giver brugerne indflydelse over den praksis, platformen medfører i form af læringssyn, kobling til målstyring og funktionaliteter (Lochner, Conrad \& Graham, 2015). En sådan vurdering er selvsagt påvirket af, hvor kompetente brugerne er til at anvende teknologien. Teknologiens kompleksitet (C), brugervenlighed og den læringskurve, der er forbundet med at kunne bruge platformen, er afgørende for adoption. Platformene er i denne sammenhæng forskellige, og platformenes koncept og forskelligartede interfacedesign har stor betydning for lærernes bedømmelse af teknologierne (Graníc \& Cukusic, 2011). Langt de fleste af platformene er mulige at afprøve på forhånd (D), men sandkassemiljøer og prøvekontoer giver sjældent et sammenhængende billede af, hvordan et system vil fungere i praksis. Mange lærere efterspørger derfor designviden i form af eksempler på pædagogisk meningsfuld brug af læringsplatformene (Jørnø \& Gynther, 2018) og ikke mindst 'de gode historier' om eksemplarisk praksis, der er nemme at kommunikere (E) til kollegaer. 


\section{Metoder}

Vi skelner metodisk mellem projektets overordnede metode, de metodiske overvejelser i forbindelse med arbejdet med modellen udført i løbet af projektet og endelig denne artikels metodiske greb.

Skolernes implementering af læringsplatformene er i projektet blevet initieret af to projektinterventioner: a) Afholdelse af fremtidsværksted (Jungk \& Müllert, 1987), og b) introduktion til og igangsættelse af designeksperimenter gennem afholdelse af designworkshops. Både fremtidsværksteder og designworkshops har været faciliteret af et team bestående af en forsker og en konsulent. Efterfølgende har forskere og konsulenter indsamlet data fra afprøvningerne af de i projektet udviklede designs. Denne artikel bygger på data fra dette projekt.

Som afsæt for denne artikel har vi kombineret dybdegående casestudier på to skoler med projektets tværgående dataindsamling. Der er foretaget en kvalitativ analyse inspireret af Grounded Theory (Glaser \& Strauss, 1967/2008) af følgende data:

- Casestudier fra to skoler, hvor interventionsdesignet (fremtidsværksted, designworkshop, mikroafprøvninger samt real life-afprøvningen) er blevet observeret og fastholdt $i$ forskningsnoter, ligesom der er foretaget supplerende interviews med deltagerne.

- Afsluttende fokusgruppeinterviews på de deltagende skoler med afsæt i en fælles interviewguide. 12 interviews er transskriberet og analyseret (i alt ca. 240 sider).

— Dokumentstudier af projektdeltagernes designdokumenter, hvor designscenarier er beskrevet og designeksperimenterne planlagt.

\section{Præsentation af double-loop lærings- modellen - en organisatorisk model til understøttelse af implementering af digitale læringsplatforme i skolen}

I det følgende præsenterer vi en organisatorisk model, som er udviklet med henblik på at understøtte implementeringen af digitale læringsplatforme. Modellen kan således anvendes i eksisterende eller fremtidige implementeringprocesser, hvor brugerne af platformene inddrages i udviklingen af nye innovative pædagogiske praksisformer. 
Figur 1. En dobbeltloop læringsmodel til implementering af læringsplatforme i skolen.

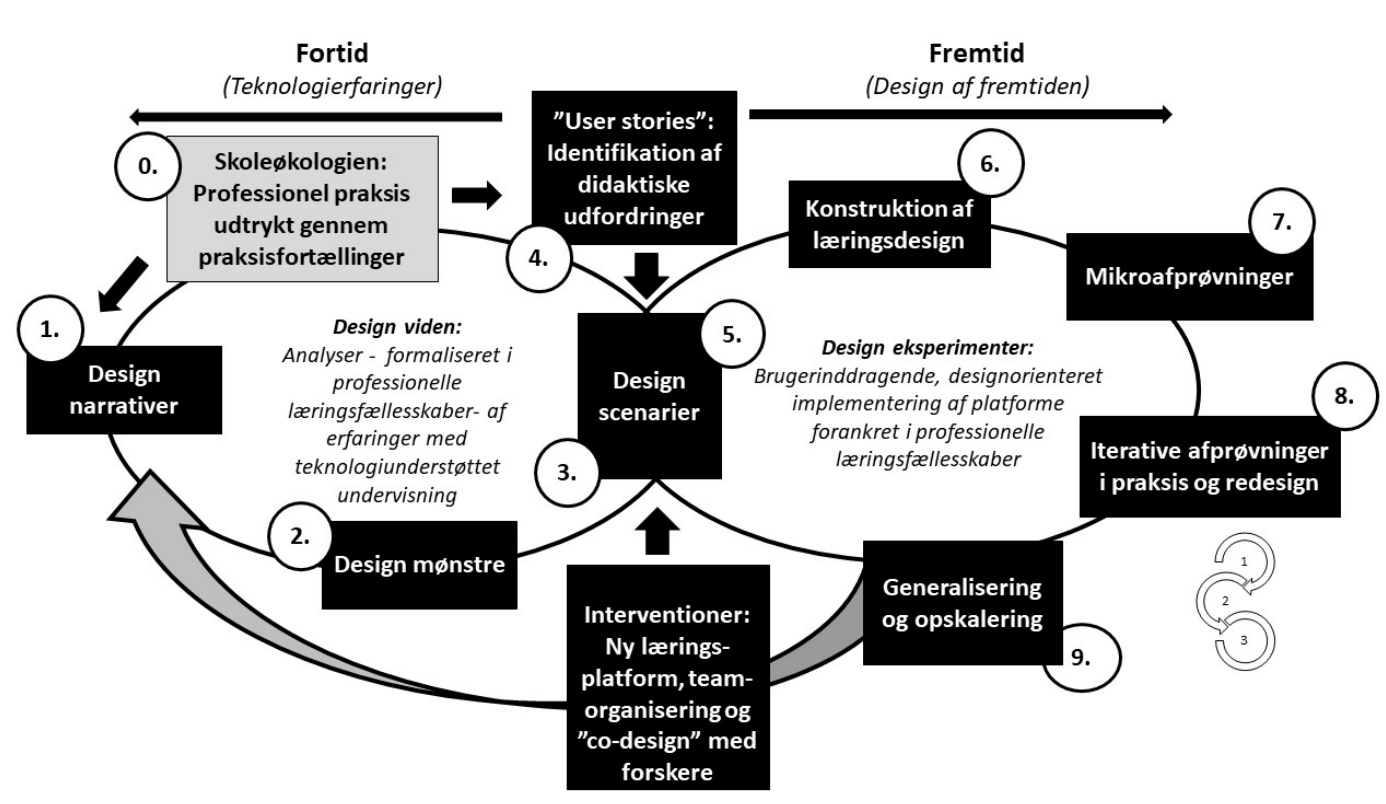

Modellen er et forsøg på at iværksætte og konceptualisere deltagerstyrede designeksperimenter, der kan bidrage til at understøtte lærere i at udvikle meningsfulde nye praksisformer i og med anvendelsen af de digitale platforme. Modellen bygger på Design-Based Research-idéer om, hvordan man kan dele og udbrede designviden vedrørende eksemplariske erfaringer med anvendelse af de digitale læringsplatforme på en måde, som understøtter udviklingen af nye innovative læringsdesign med afsæt i givne teknologi-'constraints' ved platformene. I arbejdet med modellen er der primært blevet trukket teoretisk på Design Based Research (DBR)(Anderson \& Shattuck, 2012; Barab, 2004; McKenney \& Reeves, 2012) særligt den tradition inden for DBR, hvor forskere og praksis i et co-designfællesskab idégenererer, udvikler, konstruerer og tester nye løsninger med afsæt i en fælles analyse af eksisterende didaktiske problemer (Collins, 1992; Dede, 2004). 


\section{Brugerinddragelse}

Brugerinddragelse er et centralt afsæt for modellens udformning. Det er for så vidt velkendt, at implementering af nye teknologier i skolen kan understøttes af en brugerinddragende designorienteret tilgang, sådan som vi ser det i brugen af designeksperimenter i Design-Based Research (Anderson \& Shattuck, 2012; McKenney \& Reeves, 2012) og Action Research (Kemmis, 2007), som begge understreger vigtigheden af brugerinddragelse. Inden for Design-Based Research findes der imidlertid flere forskellige traditioner og syn på brugerinvolvering. Nogle argumenterer for, at nye design skal udvikles af forskere med afsæt i en hypotese og en indsigt i det problem, som designet skal løse (Brown, 1992; diSessa \& Cobb, 2004). Andre mener, at det er vigtigt og nødvendigt at inkludere brugerne i designprocessens forskellige faser (Amiel \& Reeves, 2008; Anderson \& Shattuck, 2012; Collins, 1992; Dede, 2004), fordi brugerne er dem, som har viden om den kontekst, designet skal indgå i. Derfor skal brugerne inddrages aktivt og ligeværdigt som co-designere i både problemidentifikationen og designfasen (Collins, 1992; Barab, 2004; Dede, 2004), hvilket bidrager til, at de får ejerskab til designet (The Design-Based Research Collective, 2003). I dette projekt har lærerne deltaget ligeværdigt som co-designere i at udvikle og teste nye design i en iterativ designproces.

\section{Implementeringsfaser}

Modellen er baseret på følgende designfaser:

- Identifikation af didaktiske udfordringer.

— Designscenarier: Idégenerering og designskitsering.

- Konstruktion af loeringsdesign: Planlægning af måder at bruge læringsplatformen på.

— Mikroafprøvning: Afprøvning af prototype (eller element i prototypen) i en simuleret kontekst samt redesign af final prototype.

- Designafprøvning i praksis (iterative cirkler, hvor designløsninger afprøves med reelle brugere og justeres med afsæt i evaluering og analyse af indsamlede erfaringer).

- Generalisering og skalering: Designnarrativer fra designeksperimenterne analyseres og generaliseres om muligt til designmønstre, der kan deles med alle på skolen. 
De fleste af ovenstående faser er velkendte for mange lærere og pædagoger i skolen, som arbejder designorienteret. Disse faser er ofte benyttede inden for DBR (McKenney \& Reeves, 2012) samt inden for aktionslæring (Bayer, Plaugborg \& Andersen, 2007) og lektionsstudier (Bilsted, 2010), hvor de to sidstnævnte dog arbejder med et lidt andet begrebsapparat.

\section{Designeksperimenter}

Et vigtigt element i modellen er designeksperimenter. Designeksperimenter vedrørende udvikling af nye didaktiske design i og med de digitale læringsplatforme er struktureret med afsæt i velkendte faser inden for DBR-traditionen:

a) Identifikation og analyse af problemer i praksis,

b) Konstruktion af læringsdesign, c) Iterativ afprøvning i praksis, d) Analyse og redesign, e) Refleksion og generalisering. Selvom DBR-litteraturen understreger, at afprøvninger skal foregå i "real life settings" og ikke i et "laboratorium" (Brown, 1992), så har vi imidlertid erfaringer med, at overgangen mellem konstruktionen af prototyper for et læringsdesign og så selve afprøvningen af prototypen i praksis med elever for mange lærere er et problem, når de står med nye teknologier i klasserummet. Vi har derfor til dette forskningsprojekt udviklet en metode, vi kalder "mikroafprøvninger". Her afprøver lærerne i en simuleret klasserumskontekst deres læringsdesign med brug af den nye platform med henblik på at fange "støj", som ved små ændringer af designet kan fjernes, inden læringsdesignet afprøves med elever (og/eller forældre).

\section{Mikroafprøvninger}

En mikroafprøvning er en realistisk simulering, hvor en projektgruppe (eksempelvis et pædagogisk team) afprøver fejl og mangler ved et læringsdesign, som integrerer ny teknologi, inden det afprøves af reelle brugere - som kan være elever, forældre eller kollegaer. Fx oplever mange lærere små tekniske problemer, når de første gang implementerer en digital teknologi i undervisningen. Mikroafprøvningen er her en forfase til afprøvningen af en prototype for et nyt læringsdesign. Mikroafprøvningen afprøver ikke hele designet, men kun en mindre udvalgt sekvens, hvor designteamet spiller rollen som brugere (lærere og elever eller lærere og forældre). Der vælges her en sekvens, som er velegnet til at fange forskellige former for "støj", der har betydning for om designets potentiale kan afprøves af rigtige brugere. "Støj" kan fx 
være, at lærere eller elever ikke kan få en teknologi til at fungere første gang de prøver den - fx fordi instruktionen ikke har været god nok. Sekvensen, der afprøves i en mikroafprøvning, skal indeholde relevante og væsentlige aktiviteter, der kan teste designets primære potentiale, dvs. sekvensen skal være eksemplarisk.

\section{Deling af erfaringer i faglige fællesskaber}

Modellen tager endvidere afsæt i den idé, at en proces, der indsamler og deler erfaringer om eksemplarisk brug af en digital teknologi (et loop), kan bruges som afsæt for nye designeksperimenter (et andet loop). En sådan dobbeltloop læringsmodel indeholder et større læringspotentiale for deltagerne end blot at arbejde designorienteret. Inspirationen til modellen er Mors og Warbuttons arbejde med en dobbeltloop designmodel, som indeholder såvel videndelingen og designeksperimentet (Warburton \& Mor, 2015b). Deres model har imidlertid ikke fokus på den konkrete praksis i en implementering og kan derfor ikke anvendes til at forklare, hvorfor skoler udvikler forskellige grader af innovative læringsdesign. Som supplement til Warburton og Mors model trækker vi derfor også på et forslag til revision af den udbredte fasemodel i DBR, som er udarbejdet af Mor, Cook, Santos, Treasure-Jones, Elferink, Holley og Griffin (2015). Her præciseres, at afsættet for innovationen er en konkret praksis beskrevet gennem praksisfortællinger og "user stories" for en ny bedre praksis. Den konkrete professionelle lærerpraksis i form af en konkret skoleøkologi er derfor medtaget i modellen.

\section{Et format for deling af erfaringer - designnarrativer og designmønstre}

Modellen tilbyder først og fremmest et sprog og et medieformat for deling af designviden mellem lærerne på en skole. Dobbeltloop læringsmodellen er formet omkring begreberne: "Designmønstre", "designnarrativer" og "designscenarier" (Mor, 2013). Disse begreber handler om deling af designviden som eksemplarisk brug af platformene og/eller andre digitale teknologier anvendt til teknologiunderstøttet undervisning og læring. Et designnarrativ indsamler således brugeres viden om, hvordan et design virker i praksis. I et DBR-projekt indgår der to forskellige slags narrativer: Forskernarrativer og deltagernarrativer (lærer og elever og evt. forældre) (Mor, 2011). Med afsæt i analyser af en række designscenarier er det muligt at udlede en "situeret abstraktion" i form af et designmønster. Et "designmønster" forstår vi i denne 
sammenhæng som et "pædagogisk mønster" (Laurillard, 2012) i form af en semistruktureret beskrivelse af erfarne underviseres metode til at løse et pædagogisk problem - en beskrivelse som altid indeholder en beskrivelse af problem, løsning og den kontekst, løsningen har fungeret i (Mor \& Winters, 2007). Et design mønster fungerer som eksternaliseret viden (Goodyear, 2005), der kan deles i et fagligt fællesskab af undervisere (Laurillard, 2012). Det, at designmønsteret er skabt, delt, kritiseret og videreudviklet i en kollaborationsproces mellem medlemmer af et fagligt fællesskab (McAndrew, Goodyear \& Dalziel, 2006), legitimerer teknologien og giver ejerskab i forhold til implementeringsprocessen. Designmønstre kan udledes både gennem forskningsinitierede designeksperimenter, der integrerer analyser af designnarrativer fra de iværksatte eksperimenter, og gennem analyser af indsamlede designnarrativer fra erfarne underviseres løbende praksiserfaringer (Mor, 2013; Warburton \& Mor, 2015a).

Endelig giver muligheden for at skabe "designscenarier" liv og krop til det Paaskesen og Nørgaard (2016) kalder teknologisk forestillingskraft. "Designscenarier" kan forstås på forskellig vis, idet det både kan fungere som en videnskabelig analysekategori og som et praktisk designværktøj (Mor, 2013). Anvendt som en videnskabelig analysekategori kan et "designscenarie" anvendes til at validere de designudsagn, som kan udledes af et designnarrativ, og som efterfølgende er blevet generaliseret i et designmønster. Dette foregår gennem en analyse af, om et mønster opleves som virkningsfuld på en række hypotetiske scenarier, hvor et mønster kan indgå. Validiteten af et mønster øges, hvis det opleves som meningsfuld ikke kun på den praksis, som allerede er oplevet og beskrevet gennem et narrativ, men også på en hypotetisk fremtidig didaktisk praksis. Men herved bliver et designscenarie også et stærkt designværktøj for en læringsdesigner. Et designscenarie indeholder på samme måde som et designnarrativ og et designmønster en beskrivelse af en kontekst - en udfordring - en løsning og et forventet resultat, men formuleret som et udkast til fremtiden om resultatet eller virkningen. Designscenarier fungerer derfor særdeles godt som afsæt for tilrettelæggelsen af nye designeksperimenter. Med andre ord får fantasien noget at arbejde med. Begrebet "designscenarier" har derved en dobbeltrolle i et DBR-projekt, idet det både kan opsamle refleksioner om allerede erhvervede erfaringer og anvendes som afsæt for design af ny praksis (Warburton \& Mor, 2015 b).

Anvendelsen af ovenstående begreber handler således om 
mere end at skulle generere designs. Det indebærer også at give stemme til deltagernes praksiserfaringer i implementeringen, herunder at etablere rum for en kritisk tematisering af formål og design af de nye læringsplatforme. Vi har i dette projekt anvendt "fremtidsværkstedsformen" (Jungk \& Müllert, 1987) til at få sådanne praksisfortællinger i tale og samtidig åbne for fantasier om en ny og bedre praksis i og med de digitale læringsplatforme, som efterfølgende er transformeret til "user stories" og realiserbare scenarier for ny bedre praksis.

\section{Modellens anvendelse - helt konkret}

Modellen er fleksibel og kan anvendes på mange måder. I et større samlet skoleudviklingsprojekt på en skole eller i en kommune vil man kunne anvende alle faser i modellen. I det følgende gennemgås modellens elementer.

Modellen skal læses efter de markerede numre i Figur 1 fra 0 til 9. Første loop handler om at indsamle skolens eksisterende erfaringer. Fremtidsværkstedsformen anvendes i fase 0 til at identificere og beskrive kritiske praksisfortællinger med de implementerede teknologier. Her starter man med i formaliserede pædagogiske teams at tematisere deltagernes kritiske erfaringer med tidligere teknologiimplementeringer. Såfremt skolen allerede har erfaringer med brug af den digitale læringsplatform, foretages efterfølgende en systematisk indsamling af beretninger om eksemplarisk brug af platformene ('1' - designnarrativer). Disse fastholdes i tekst og billeder med henblik på deling på skolen. Har flere lærere samme erfaringer, genereres et "designmønster" ('2') af disse til eksemplarisk brug, som styrker, at det skal udbredes til alle på skolen. Ofte indfanger et designmønster situationer, som andre lærere er i stand til at generere idéer ud fra om mulig brug af det eksemplariske mønster i deres fag og klasser. I det omfang, at mønstret valideres, anvendes det til at udforme hypotetiske designscenarier ('3'). Ved sådan en anvendelse har man samtidigt taget hul på et nyt designeksperiment. Designeksperimenter starter med fase 4, i modellen: Identifikation af didaktiske udfordringer ('4'). Dette indebærer, at anvendelsen af digitale læringsplatforme skal have didaktisk merværdi. Det vil sige, at teknologien skal bidrage til at løse et didaktisk problem i skolens nuværende praksis. Igen i teams formulerer en pædagogisk faggruppe derefter konkrete designscenarier (' 5 ') for deres designeksperiment med platformen. Teamet udvikler og beskriver herunder et læringsdesign og plan- 
lægger et læringsforløb med brug af platformen ('6'). Derefter kommer den for mange undervisere nye fase: Mikroafprøvningen (' 7 '). Det er vigtigt at prøve designet i det pædagogiske team, inden man udsætter elever, forældre eller kollegaer for designet. Mikroafprøvningen fanger og minimerer fejl i designet, inden det i fase 8 i modellen afprøves med rigtige brugere ('8'). I denne fase afprøves designet af nogle gange i en iterativ proces. Den sidste fase i modellen er generalisering af erfaringer ('9'). Spørgsmålet her er, hvorvidt der kan genereres nye designnarrativer og nye designmønstre, der kan skaleres op og deles med alle på skolen? Har designeksperimentet skabt ny designviden?

Modellen kan anvendes uden, at man som skole gennemgår alle faser i modellen. For eksempel kan en skole gå direkte til designeksperimentet og starte med fase 4, hvor deltagerne begynder med at formulere konkrete "user stories" med afsæt $\mathrm{i}$ identificerede didaktiske udfordringer, man gerne vil have en bedre løsning på. Man kan også starte et større aktionslæringsprojekt med fase o og derefter springe frem til designeksperimentet (fase 4 og frem). Modellen kan også understøtte vidensgenerering og videndeling i professionelle læringsfællesskaber på skolen efterhånden, som en skole får flere og flere erfaringer med brugen af læringsplatformene. Her vil man anvende fase o-3 til at understøtte denne proces. Modellen er samtidig dynamisk i tid, idet fikspunktet mellem fortid og fremtid for en konkret skole hele tiden flytter sig. Dette er blandt andet visualiseret i fase 9 med en pil fra fase 9 til fase 1 i modellen, hvor generalisering af erfaringerne fra et designeksperiment kan repræsenteres og deles i nye designnarrativer og designmønstre. Det afgørende ved anvendelse af modellen er imidlertid, at man altid starter en udviklingsproces med afsæt i den konkrete skole$\emptyset$ kologi og udvikler skolen med afsæt heri.

\section{Det dobbelte klasserum - et konkret eksempel på et designmønster}

Med inspiration fra Goodyear (2005) har vi udviklet nedenstående skabelon til konkret beskrivelse af et designmønster for en pædagogisk meningsfuld brug af læringsplatforme. Vi eksemplificerer anvendelsen af skabelonen ved at beskrive et enkelt designmønster identificeret i datamaterialet. Designmønsteret tager afsæt i erfaringer fra en enkelt caseskole (Se Nortvig, 2019, i dette temanummer). Designmønstre kan beskrives og visuali- 
seres på mange måder, men er ofte inspireret af Alexander (1997, bearbejdet af Goodyear, 2005) og indeholder: Kontekst, problemet i overskriftform, problemuddybning, løsningsbeskrivelse beskrevet som en instruktion, et diagram for løsningen samt refleksion vedrørende hvilke andre "mønstre", der er nødvendige for at iværksætte løsningen.

\begin{tabular}{|c|c|}
\hline $\begin{array}{l}\text { Titel på } \\
\text { designmønster }\end{array}$ & Det dobbelte klasserum / fordobling af læreren \\
\hline $\begin{array}{l}\text { Kontekst: } \\
\text { Beskriv den } \\
\text { skolekontekst, } \\
\text { som brugen af } \\
\text { læringsplatformen } \\
\text { er genereret i. }\end{array}$ & $\begin{array}{l}\text { De praktisk-musiske fag i folkeskolen har en række fælles træk. Det være } \\
\text { sig rammevilkår (antal lektioner, placering på klassetrin, eksamensfrihed, } \\
\text { undervisning i faglokaler mv.), ligesom de fagdidaktisk har fælles træk } \\
\text { i måden at formulere kompetencemål på, men ikke mindst i forhold til } \\
\text { elevernes erkendeformer (kropslig, æstetisk læring i og med materialer } \\
\text { og værktøjer) og lærerens rolle i læreprocessen (direkte instruktion og } \\
\text { feedback). }\end{array}$ \\
\hline $\begin{array}{l}\text { Problem: } \\
\text { Beskriv - i kort } \\
\text { form - det didak- } \\
\text { tiske problem, som } \\
\text { læringsplatformen } \\
\text { skal bidrage til at } \\
\text { løse. }\end{array}$ & $\begin{array}{l}\text { Det er en fælles udfordring for de praktisk-musiske fag, at underviseren } \\
\text { ikke i tid og rum kan instruere, guide og give feedback til den enkelte } \\
\text { elev (og grupper af elever) i det omfang, der er behov for det. }\end{array}$ \\
\hline $\begin{array}{l}\text { Kernen i } \\
\text { problemet: } \\
\text { Uddyb problemet. } \\
\text { Hvad er det } \\
\text { empiriske grundlag } \\
\text { for problemet? }\end{array}$ & $\begin{array}{l}\text { Et øjebliksbillede fra "sløjdlokalet" (materielt design): } \\
\text { Læreren har givet en fælles instruktion. Eleverne er i gang. Kort tid efter } \\
\text { opstår der et udbredt behov for lærerhjælp hos mange elever. Elever må } \\
\text { skrive sig på en hjælpeliste. Ingen elever har adgang til den indledende } \\
\text { instruktion, men må vente på supplerende instruktion og feedback, når } \\
\text { læreren har tid. }\end{array}$ \\
\hline $\begin{array}{l}\text { Løsning: } \\
\text { Beskriv løsningen } \\
\text { som en instruktion. } \\
\text { Hvordan skal man } \\
\text { konkret anvende } \\
\text { platformen? } \\
\text { Hvem skal gøre } \\
\text { hvad med } \\
\text { platformen? }\end{array}$ & $\begin{array}{l}\text { Følgende projekteksempel er fra faget musik: } \\
\text { - Læreren har på video optaget, hvordan man skal klappe en rytme. } \\
\text { Desuden instrueres eleverne i videoen i, hvordan de skal udføre og } \\
\text { videooptage øvelsen. } \\
\text { - Lærerens video lægges på platformen, så alle elever kan tilgå den, } \\
\text { når timen starter. } \\
\text { - Læreren giver en traditionel instruktion i starten af timen. } \\
\text { - Eleverne begynder at øve rytmen. Bliver de i tvivl, så kigges der på } \\
\text { videoen, hvis læreren ikke har tid til at hjælpe. } \\
\text { - Videoen kan også ses derhjemme - elever får rytmeøvelser for som } \\
\text { lektie. (Det dobbelte klasserum bliver også et parallelt klasserum } \\
\text { - hvilket ikke har været praksis i de praktisk-musiske fag tidligere). } \\
\text { - Eleverne optager deres rytmer på video (parvis). Eleverne ser deres } \\
\text { video og kan nu iagttage deres egen performance (som spejlet hos } \\
\text { en balletdanser). } \\
\text { - Eleverne øver igen og optager igen, til de er tilfredse. } \\
\text { - Eleverne lægger deres video på platformen. } \\
\text { - Læreren kigger alle videoer igennem og giver feedback både i klassen, } \\
\text { men også i platformen. } \\
\text { - Derefter får eleverne en ny kreativ opgave med lyd og rytmer. } \\
\text { Processen gentages, men denne gang deler eleverne deres video } \\
\text { med hele klassen. Platformen bliver afsæt for et læringsfællesskab, } \\
\text { hvor eleverne inspirerer hinanden til sjove, kreative æstetiske } \\
\text { løsninger på opgaven. }\end{array}$ \\
\hline
\end{tabular}


Visualisering:

En skitse eller et diagram, som viser et eksempel på, hvordan platformen er brugt til at løse et didaktisk problem.
Forudsætninger: Hvilke teknologiske og sociale relationer på skolen er nødvendige for at etablere løsningen - herunder tekniske krav til læringsplatformen, lærergruppens didaktiske scenariekompetence samt en generel teknologiforståelse hos alle de aktører, som skal bruge platformen?
"Det dobbelte klasserum i billedkunst"
Direkte instruktion

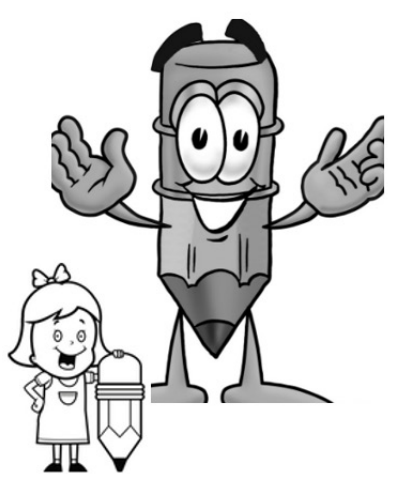

Videoinstruktion

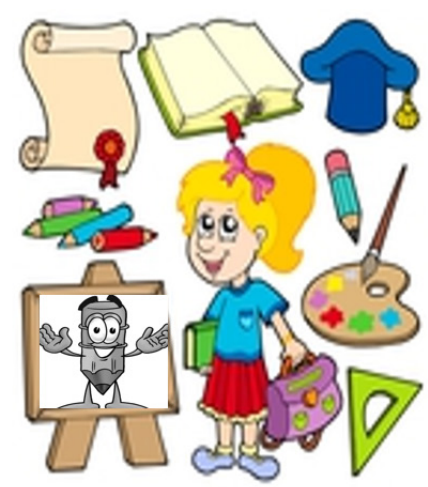

- Teknologien er driftssikker.

- Der er er netadgang alle steder på skolen samt hjemme hos forældrene.

- Elever og lærere er erfarne brugere af platformen.

- Lærerens scenariekompetencer til at se nye didaktiske muligheder i de praktisk-musiske fag er gode og tager afsæt i en teknologiforståelse og et opdateret fagsyn, der betyder, at læreren kan forholde sig kritisk konstruktivt til potentialet i læringsplatformene i de praktisk-musiske fag.

- Det handler i særlig grad om at kunne kombinere et fagsyn, som sætter fokus på erkendelsespotentialet i kropslig-æstetisk arbejde med materialer, værktøjer i og med materielle designs - med nye digitale undervisningsmuligheder - og efterfølgende anvende platformen med afsæt heri.

\section{Fund}

I det følgende giver vi et indblik i og eksemplificerer den omfattende empiri, der er indsamlet om deltagernes erfaringer med at afprøve elementer i implementeringsmodellen. Fundene fra datamaterialet er tematiseret i relation til de elementer i Rogers teori, der blev introduceret i teoriafsnittet.

Designeksperimenterne var i projektet understøttet af et interventionsdesign centreret omkring designworkshops. På disse workshops har der været arbejdet med udvikling af designscenarier for pædagogisk meningsfuld brug af platformene, metoden "mikroafprøvning" er blevet introduceret, og deltagerne har fået 
introduktion til, hvordan de kunne tilrettelægge et mindre designeksperiment, hvor de udvikler og afprøver et læringsdesign gennem en iterativ proces. Med afsæt i den skitserede implementeringsmodel udviklede de deltagende skoler en række designnarrativer, som beskriver en eksemplarisk meningsfuld brug af læringsplatformene i forbindelse med at løse et pædagogisk problem, som deltagerne havde identificeret. I datamaterialet er identificeret 15 forskellige narrativer. Tre af de identificerede designnarrativer kan generaliseres til egentlige designmønstre, idet flere forskellige projektgrupper har identificeret designpotentialet, og/eller designpotentialet er blevet fastholdt af en projektgruppe og efterfølgende delt med kollegaer, som har afprøvet designet med samme succes: a) "Inddragelse afforceldre i loeringsprocessen", b) "Teamsamarbejde", og c) "Loringsplatformen som afscet for forceldresamtaler". Derudover kan man også betragte designnarrativet "Det dobbelte klasserum" (er eksemplificeret tidligere i artiklen) som et valideret designmønster, idet vi også har set og beskrevet dette mønster i et andet forskningsprojekt (Nortvig \& Gynther, 2017). Sidstnævnte designmønster beskriver og visualiserer, hvordan man gennem videoinstruktioner kan "fordoble" læreren i klasserummet og derved løse problemet vedrørende behovet for løbende lærerinstruktion specielt i de praktisk-musiske fag.

De tværgående fokusgruppeinterviews viser, at der har været stor tilfredshed med de afviklede designworkshops og mere bredt at arbejde med designeksperimenter som en del af en brugerinddragende implementeringsmetode.

99

Den her måde at lave workshop på gør bare, at du så kommer frem til en rigtig fed løsning, som faktisk ikke var særlig svær at finde frem til, som går ud og løser nogle problemer. Vi er faktisk meget stolte over, at vi har løst nogle af de problemer, vi selv synes, vi havde inden, som var gigantiske. (Lærer)

Der er tilsyneladende efter afholdelsen af workshops skabt et fundament for positive fortællinger omkring læringsplatformen, men det er uklart, om dette resulterer i, om dette opleves, som at læringsplatformen besidder en relativ fordel (A). Udsagnet skal ses på en baggrund af en del skepsis vedrørende læringsplatformenes kompatibilitet (B) med lærernes syn på skolens opgave 
eller deres pædagogiske grundantagelser. For en del lærere kommer dette til udtryk ved, at der bliver stillet spørgsmålstegn ved producentens motiver og faglige forankring.

99

Platformen er jo bundet på tvivlsomme pædagogiske teorier. (Lærer)

99 Der findes ikke en platform, der kan lave læring. (Lærer)

99 De diskussioner, vi har haft med kritikken af læringsmålsstyret undervisning er jo præcis den kritik, der ligger til grobund for, at folk ikke har lyst eller tænker, det er effektivt at bruge det her værktøj.

(Lærer)

Projektets interventionsdesign etablerede rum for tematisering af kritiske erfaringer. Deltagernes kritik rettede sig i særlig grad mod uhensigtsmæssigt platformsdesign, og deltagerne udtrykte langt oftere kritik af platformene, fremfor en positiv vurdering af de nye teknologier. Nedenstående citater er alle fra fokusgruppeinterviewene på de 15 skoler:

99 Jo mere man kommer ind i det, jo dårligere bliver det faktisk. (Lærer)

99

Der er bare så mange børnesygdomme endnu, at jeg ikke orker at bruge det.

(Lærer)

Der henvises også ofte til "tid" som en vigtig kategori, der kritisk tematiseres flere gange i materialet. Der er her tale om tre typer af tidsproblematikker. Den velkendte, der handler om, at implementering af ny praksis kræver tid, og at dette efter deltagernes overbevisning er en mangelvare i skolen i dag. Men deltagerne peger også på, at selve det at bruge en platform er tidskrævende både for lærerne og for eleverne. 
Men nogle gange, de ting, der lige skal tage 5 minutter, det bruger man ti minutter til et kvarter på. Der er også så meget tidsspild, det skal man lige overveje.

(Lærer)

Og så peger deltagerne på en særlig vigtig kategori, nemlig det dobbeltarbejde de oplever, at implementeringen af platformene giver for deltagerne.

99 Så skal du nærmest lave to ting på en eller anden måde. Så bliver det tidskrævende.

(Lærer)

99 Det, der kommer ind i X-platform, skal også ligge et andet sted, så det er vel bare dobbeltarbejde at lægge det ind i platformen også.

(Lærer)

Men disse problematiseringer røber ikke, hvorvidt undervisernes skepsis er genereret på baggrund af dybtgående afprøvninger og faglige vurderinger, eller om de snarere fungerer som alibier for at fastholde eksisterende praksis og afvise 'den nye teknologi' over én kam. En lærer udtrykker afvejningen direkte:

99 Det er jo ret tåbeligt at skifte til noget, som er dårligere end det, vi har i forvejen.

(Lærer)

For nogle kulminerer den kritiske indstilling i et fokus på organisatoriske og strukturelle problemstillinger omkring implementering af ny teknologi. Det bliver således lynhurtigt et spørgsmål om magt. Flere lærere er således meget optaget af at få lokal indflydelse på det, de betragter som en "top down"-beslutning vedrørende implementering af de digitale platforme. I materialet kan vi se stærke reaktioner på, at implementering af digitale platforme er besluttet "ovenfra" og en bekymring for, at det bliver sværere for det pædagogiske personale at få indflydelse på, i hvilket omfang og til hvad platformene skal anvendes. 
Det er blevet et politisk prestigeprojekt, så jeg har den der tanke, at uanset hvor uanvendeligt det så viser sig at være, så er det bare noget, vi skal. Det er jeg lidt bekymret for.

(Lærer)

Fraværet af en synlig relativ fordel (A) og den umiddelbare vurdering af manglende kompatibilitet (B), oplevelsen af tidspres og et ydre pres for implementering er tæt sammenvævet med den erfaring (eller her mangel på samme), brugerne har med systemet. Som med alle systemer vil muligheden for at afprøve systemet (D), det vil her sige få et indblik i dets muligheder, være betinget af en relation: Forholdet mellem brugernes digitale kompetencer (mere generelt af niveauet for deres digitale dannelse) og systemets kompleksitet (C) set over tid. Afhængig af den enkelte bruger og undervisergruppens generelle niveau kræver udfoldelsen af systemets potentialer derfor som regel en stor investering i tid og energi; ligesom der må påregnes et dyk i effektivitet (et såkaldt implementeringsdyp (Fullan, 2002)). Har en skole ikke tidligere erfaringer med en læringsplatform, eller har skolen ikke systematisk indsamlet og delt designviden i professionelle læringsfællesskaber om eksemplarisk brug af platformene, er det langt vanskeligere at få øje på potentialet:

99 Og så det her med at udnytte det optimalt og bruge det fuldt ud, så det ikke bare bliver fladt, og vi bare skriver læringsmål ind. Det kan jo helt vildt meget, men man skal ligesom sættes ind i det og i gang med det, få det under huden, før det begynder at glide.

(Lærer)

Dette kan ses som et problem for den enkelte:

99

Der er nogle, der sidder og kæmper for at få lagt film ind, og så bliver det ikke gjort, og så mister de modet. Der er virkelig nogle, som rent teknisk ryger af. Der skal ikke meget til. (Lærer)

Men i denne sammenhæng afkoder vi det i højere grad som et spørgsmål om, i hvor høj grad den enkeltes indføring og første erfaringer med systemer er organisatorisk stilladseret i en 
kollaborativ proces. Afprøvelsen af systemet (D) handler således om andet og mere end tekniske kompetencer. Det handler i lige så høj grad om, at skolens adoption af ny teknologi indebærer udviklingen af nye praksisformer med digitale læringsplatforme. Dette kræver et fælles sprog (E) der i sidste ende kan understøtte udbredelsen af et budskab om systemets relative fordel(e) (A) og dets kompatibilitet (B). Det er således særligt det kollaborative element i designworkshops'ene, der viser sig at være eksponent for en fælles erfaringsdannelse:

99 Når vi stødte på en problematik, så hjalp vi hinanden. Vi har jo hver især fundet ud af mange ting om lige præcis den her platform, hvor jeg tænker, hvis man havde siddet med det selv, så havde man bare lukket og sagt nej, det bliver ikke i dag.

(Lærer)

Behovet for et fælles sprog og for at skabe erfaringer med teknologien (indkapslet i positive fortællinger) blev i projektet rammesat som designnarrativer og designmønstre. Narrativerne og mønstrene binder det fælles sprog og erfaringer sammen med teknologiens (oplevede) relevante fordele forstået som 'pædagogisk meningsfuld brug af platformene:

99

Når vi skal have sådan en platform, så skal vi jo bruge den der, hvor det giver mening ..., men jeg tror, vi er lidt enige om alle sammen, at vi mangler måske at se noget eksemplarisk selv, for at vi helt kan se meningen. (Lærer)

Materialet viser også, at de skoler som er nået så langt, at de er begyndt at dele eksemplariske anvendelser af platformen i form af designnarrativer eller designmønstre, netop flytter flere hen imod en adoption af teknologien:

99

Så jeg kan godt forstå kollegaer, der siger, når I synes det er smart, vil jeg gerne være med, men indtil da, nej. (Lærer) 
De andre teams de bruger det alle sammen. Jeg kan få hele teamet til at bruge det. Det er stort... Så jeg synes, det rykker på noget, vi ikke kunne få dem til at rykke på før.

(Lærer)

Oplevelsen af et større engagement baner vejen for at øge kompleksiteten i de designs, der fremkom. Med andre ord baner de eksemplariske narrativer vejen for bedre mere innovative designs og opbygning af brugernes kompetencer. Mikroafprøvningerne var særligt effektive til at identificere "støj" ved designet, dvs. små elementer som nemt kunne rettes, men som kunne afspore afprøvningen med reelle brugere, hvis de ikke blev fanget og rettet.

99

Det der støj, vi selv har set, det er det, der også har rykket os. Og det havde man ikke mødt, hvis vi ikke havde været igennem den her proces.

(Lærer)

Et casestudie af en enkelt projektgruppes mikroafprøvninger identificerer over 10 gange, hvor projektgruppen registrerer et "støjende" element i deres design, som de vælger at ændre inden første afprøvning med reelle brugere.

Der er ydermere antydninger af, at projektets mere overordnede teoretiske ambition om at skabe grobund for designtænkning på et højere niveau kan indfries ved at stilladsere designarbejdet. I datamaterialet er der to eksempler på, hvordan designscenarier og designmønstre valideres gennem hypotetiske designscenarier. I disse tilfælde er det muligt at generere et meget stærkt engagement for udbredelsen af et designmønster til hele skolen.

99 Der finder du ud af, at nogle af de løsninger, der er, de er bare universelle, ligesom vores skema, som viste sig at være universel.

(Lærer) 


\section{Konklusion}

Der findes mange forskellige innovationsdrivere - i denne sammenhæng forstået som grunde til at adoptere ny teknologi. Blandt disse drivere kan tælles et omverdenspres på den ydelse, man leverer, nye arbejdsorganiseringsformer, nye teknologier, ny viden og kompetenceudvikling samt ikke mindst et skift i mening hos brugerne af bestemte praksisformer (Norman \& Verganti, 2014). Men projektet illustrerer den velkendte pointe, at det at implementere en ny teknologi, eksempelvis et nyt LMS, i sig selv ikke er tilstrækkeligt for at ændre praksis. En væsentlig årsag hertil er, som anført ovenfor, at det intenderede design for platformene transformeres i og med praksis (McKenney \& Reeves, 2012). Men empirien viser også entydigt, at en god implementeringsproces er afgørende for, hvorvidt ny teknologi adopteres. Den fremsatte dobbeltloop læringsmodel bygger på den antagelse, at kombinationen af nye teknologier, en arbejdsorganisering i professionelle læringsfællesskaber og et co-design i samarbejde med forskere kan bidrage til at udvikle en ny og bedre praksis. Projektet viser, at brugerinddragelsen er nøglen til succes, forstået som medbestemmelse, erfaringsdeling, udviklingen af et sprog om den nye teknologi og ikke mindst genereringen af eksemplariske anvendelser af platformen.

De narrativer, der fremkommer i designarbejdet, er ikke 'bare historier,' men udgør omdrejningspunktet for praksisændringer, der er nødvendige for en adoption af teknologien. Dels peger de bagud og forankrer forandringerne i eksemplariske design, som er valideret af et fagligt fællesskab. Dels peger de fremad og peger på teknologiens potentialer som en horisont for udforskning. Samtidig legemliggør narrativerne det fælles sprog, som selve implementeringen er båret af. Vi kan sige, at lærernes 'teknologiske forestillingskraft' (Paaskesen \& Nørgaard, 2016) har betydning for, hvor innovative designscenarier lærerne udvikler. I relation til de digitale læringsplatforme er der her tale om kompetencen til at generere innovative design scenarier for en ny bedre undervisnings- og læringspraksis understøttet af de digitale læringsplatforme - med afsæt i eksisterende pædagogiske grundantagelser, teknologierfaringer og en generel teknologiforståelse. Designscenarier fungerer her som afsæt for planlægning, afvikling, evaluering og deling af læringsforløb understøttet af digitale læringsplatforme.

Projektets konklusioner i forhold til at arbejde designorien- 
teret som afsæt for implementering af de digitale platforme er, at der ligger en række gevinster ved at anvende den udviklede brugerinddragende dobbeltloop læringsmodel til at understøtte implementering af de digitale læringsplatforme i skolen. Deltagerne udtrykker generelt stor tilfredshed med de enkelte faser i modellen, ligesom den brugerinddragende implementeringsmetode også har vist, at den kan generere og identificere eksemplarisk, det vil sige pædagogisk meningsfuld, brug af platformene.

\section{Referencer}

Alexander, C. (1977). Pattern language: towns, buildings, construction. London: Oxford University Press.

Amiel, T. \& Reeves, T. (2008). Design-based research and educational technology: rethinking technology and the research agenda. Journal of Educational Technology \& Society, 11(4), 29-40.

Anderson, T. \& Shattuck, J. (2012). Design-based research a decade of progress in education research? Educational Researcher, 41(1), 16-25. DOI: 10.3102/0013189X11428813

Barab, S. (2004). Design-based research: putting a stake in the ground. The Journal of the Learning Sciences, 13(1), 1-14. DOI: 10.1207/s15327809jls1301_1

Bayer, M., Plauborg, H. \& Andersen, J. V. (2007). Aktionslcering - loering i og af praksis. København: Hans Reitzel forlag.

Bertelsen, P. (1997). Replikker til kommentarerne. Anthropological Psychology, 2, 51-66.

Biskjaer, M. M. \& Halskov, K. (2014). Decisive constraints as a creative resource in interaction design. Digital Creativity, 25(1), 27 61. DOI: 10.1080/14626268.2013.855239

Bilsted, E. (2010). Lektionsstudier i matematikundervisningen. En prcesentation af syv superlektioner. København: Forlaget Navimat.

Brown, A. L. (1992). Design experiments: theoretical and methodological challenges in creating complex interventions in classroom settings. The Journal of the Learning Sciences, 2 (2), 141-178. DOI: 10.1207/ S15327809jlso2O2_2

Collins, A. (1992). Toward a design science of education. I E. Scanlon \& T. O'Shea (Red.), New directions in educational technology (s. 15-22). Berlin: Springer.

Dede, C. (2004). If design-based research is the answer, what is the question? The Journal of the Learning Sciences, 13(1), 105-114. DOI: 10.1207/ s15327809jls1301_5

diSessa, A. A. \& Cobb, P. (2004) Ontological innovation and the role of theory in design experiments. The Journal of the Learning Sciences, 13(1), 77-103. DOI: 10.1207/s15327809j1s1301_4

Edmunds, B. \& Hartnett, M. (2014). Using a learning management system to personalise learning for primary school students. Journal of Open, Flexible and Distance Learning, 18(1), 11-29.

Glaser, B. G. \& Strauss, A. L. (1967/2008). The discovery of grounded theory: strategies for qualitative research. New Jersey: Aldine Transaction Publishers. 
Goodyear, P. (2005). Educational design and networked learning: patterns, pattern languages and design practice. Australasian Journal of Educational Technology, 21(1), 82-101. DOI:10.1474,2/ajet.1344

Granic, A. \& Cukusic, M. (2011). Usability testing and expert inspections complemented by educational evaluation: a case study of an e-learning platform. Educational Technology \& Society, 14(2), 107-123.

Hung, D., Lim, K. \& Huang, D. (2010). Extending and scaling technology-based innovations through research. I OECD, Inspired by Technology, Driven by Pedagogy - A systemic approach to technology-based school innovations (s. 89-102). Paris: OECD Publishing. DOI: 10.1787/9789264094437-7-en

Jørnø, R. og Gynther, K. (2018). Hvordan kan teknologi påvirke pædagogiske og didaktiske praksisser? - En analyse af implementeringen af digitale læringsplatforme i Folkeskolen. Loering og Medier (LOM), 11(18). DOI: 10.7146/lom.v10i18.96986

Jungk, R. \& Müllert, N. (1987). Future workshops: how to create desirable futures. London: Institute for Social Inventions.

Kemmis, S. \& McTaggart, R. (2007). Participatory Action Research: Communicative Action and the Public Sphere. I N. Denzin \& Y. Lincoln (Red.), Strategies of Qualitative Inquiry (s. 271-330). Thousand Oaks, CA: Sage Publishing.

Laurillard, D. (2012). Teaching as a design science. London: Routledge.

Lochner, B., Conrad, R., \& Graham, E. (2015). Secondary teachers' concerns in adopting learning management systems: a U.S. perspective. TechTrends: linking research and practice to improve learning, 59(5), 62-70. DOI: 10.1007/ S11528-015-0892-4

McAndrew, P., Goodyear, P. \& Dalziel, J. (2006). Patterns, designs and activities: unifying descriptions of learning structures. International Journal of Learning Technology, 2(3), 216-242. DOI: 10.1504/IJLT.2006.010632

McKenney, S. \& Reeves, T. C. (2012). Conducting educational design research. London \& New York: Routledge.

Mor, Y. (2011). Design narratives: an intuitive scientific form for capturing design knowledge in education. I: Sixth Chais Conference on Instructional Technologies Research, Learning in the Technological Era (s. 57-63). Raanan: Open University Isreal.

Mor, Y. (2013). Snap! Re-using, sharing and communicating designs and design knowledge using scenarios, narratives and patterns. I: R. Luckin, S. Puntambekar, P. Goodyear, B.L. Grabowski, J. Underwood \& N. Winters (Red.), Handbook of Design in Educational Technology (s. 189-200). Abingdon: Routledge.

Mor, Y., Cook, J., Santos, P., Treasure-Jones, T., Elferink, R., Holley, D. \& Griffin, J. (2015). Patterns of practice and design: towards an agile methodology for educational design research. I: G. Conole, T. Klobucar, C. Rensing, J. Konert, E. Lavvoue (Red.), Design for Teaching and Learning in a Networked World: 1oth European Conference on Technology Enhanced Learning, EC-TEL 2015 (s. 605-609). Cham: Springer. DOI: 10.1007/978-3-31924258-3_69

Mor, Y. \& Winters, N. (2007). Design approaches in technology-enhanced learning. Interactive Learning Environments, 15(1), 61-75. DOI: 10.1080/10494820601044236

Norman, D.A. \& Verganti, R. (2014). Incremental and radical innovation: Design research versus technology and meaning change. Design Issues, 30(1), 78-96. DOI: 10.1162/DESI_a_oo250 
Nortvig, A-M. \& Gynther, K. (2017). The Double Classroom: Design Patterns Using MOOCs in Teacher Education. I C. Delgado Kloos, P. Hermann, M. Pérez-Sanagustin, D.T. Seaton \& S. White (Red.), Digital Education: Out to the World and Back to the Campus. : EMOOCs 2017 (s. 254-262) (Lecture Notes in Computer Science; Bind 10254). Berlin: Springer.

Paaskesen, R. B. \& Nørgård, R. T. (2016). Designtænkning som didaktisk metode: Læringsdesign for teknologisk forestillingskraft og handlekraft. Læring og Medier, 9(16). DOI: 10.7146/lom.vgi16.24201

Rogers, E. M. (1962/1983). Diffusion of innovations. New York: The Free Press. Selwyn, N. (2011). 'It's all about standardisation' - exploring the digital (re) configuration of school management and administration. Cambridge Journal of Education, 41(4), 473-488. DOI: 10.1080/0305764X.2011.625003

Straub, E. T. (2009). Understanding Technology Adoption: Theory and Future Directions for Informal Learning. Review of Educational Research, 79(2), 625-649.

The Design-Based Research Collective. (2003). Design-based research: an emerging paradigm for educational inquiry. Educational Researcher 32(1), 5-8. DOI: 10.3102/0013189Xo32001005

Underwood, J. \& Stiller, J. (2013). Does knowing lead to doing in the case of learning platforms? Teachers and Teaching: Theory and Practice, 2O(2), 229246. DOI: 10.1080/13540602.2013.848569

Warburton, S. \& Mor, Y. (2015 a). A set of patterns for the structured design of MOOCs. Open Learning: The Journal of Open, Distance and e-Learning, 30(3), 206-220. DOI: 10.1080/02680513.2015.1100070

Warburton, S. \& Mor, Y. (2015 b). Double loop design. I M. Maina, B. Craft, \& Y. Mor (Red), The art \& science of learning design (s. 93-104). Rotterdam: Sense Publishers. 
Learning Tech - Tidsskrift for læremidler, didaktik og teknologi Udgives af Læremiddel.dk

Learning Tech er et forskningstidsskrift, hvor alle artikler er forskerbedømt i form af dobbeltblindt peer review. Tidsskriftet bringer artikler, der rammer genstandsfeltet mellem læremidler, didaktik og teknologi, og hensigten er at spille en betydelig rolle som platform for den voksende skandinaviske læremiddelforskning.

\section{Redaktion}

Stig Toke Gissel, UCL Erhvervsakademi og Professionshøjskole (ansvarshavende redaktør)

Bettina Buch, Professionshøjskolen Absalon

Hildegunn Juulsgaard Johannesen, University College Syd

René Boyer Christiansen, Professionshøjskolen Absalon

Stine Reinholdt Hansen, UCL Erhvervsakademi og Professionshøjskole

Thomas R.S. Albrechtsen, University College Syd

\section{Redaktionssekretær}

Trine Ellegaard, UCL Erhvervsakademi og Professionshøjskole

\section{Temaredaktion}

Ane Qvortrup, Syddansk Universitet

Stig Toke Gissel, UCL Erhvervsakademi og Professionshøjskole

Morten Misfeldt, Aalborg Universitet

Jens Jørgen Hansen, Syddansk Universitet

\section{Design og grafisk tilrettelæggelse}

Trefold - grafisk design og kommunikation

\section{Tryk}

Narayana Press, Gylling

ISSN 2445-7981 (Tryk)

ISSN 2445-6810 (Online)

\section{Rettigheder}

(c) 2019 Læremiddel.dk og forfatterne

\section{Kontakt}

Læremiddel.dk, Niels Bohrs Allé 1, 5230 Odense M

https://learningtech.laeremiddel.dk

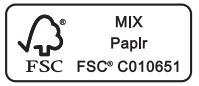

